\title{
Polen og Holocaust - polsk antisemittisme
}

\author{
Palle Andersen \\ Slagelse: Ellekjær 2018 \\ 163 sider. ISBN 9788792173331
}

Omtalt av Vibeke Moe [Phd-stipendiat, HL-senteret, vibeke.moe@hlsenteret.no]

Den danske historikeren Palle Andersens bok Polen og Holocaust: polsk antisemittisme omhandler polsk-jødiske relasjoner under 2. verdenskrig, og spesielt det polske bidraget til forsøket på å utrydde Europas jøder under Holocaust. Før 2. verdenskrig var Polen et nav for jødedommen i Europa og rommet kontinentets største jødiske befolkning med omkring 3,3 millioner mennesker. Holocaust innebar utslettelsen av omkring $90 \%$ av denne befolkningen, tilsvarende halvparten av det totale antallet jødiske ofre, en nesten ufattelig tragedie som etterlot et varig kulturelt og menneskelig tomrom i landet. Folkemordet på jødene ville ikke ha vært mulig i det omfanget det skjedde uten omfattende bistand fra lokalbefolkningen i de okkuperte områdene. Imidlertid var forholdene i Polen kanskje særlig vanskelige for jødene, og Andersens bok forsøker nettopp å beskrive hva som kan ha bidratt til dette. Boken utkommer på et tidspunkt da historien om Holocaust på nytt utgjør kjernen i en kamp om det nasjonale narrativ om 2. verdenskrig i Polen. Et av de siste tilskuddene til denne kampen kom tidligere i år, da regjeringen fikk gjennomslag for en lov som gjør det straffbart å referere til polsk involvering i Nazi-Tysklands forbrytelser. Dette bakteppet er tydelig til stede i boken gjennom et eget kapittel som drøfter de senere års utvikling i kampen om historien.

Boken konsentrerer seg om situasjonen i det såkalte Generalguvernementet, det vil si den delen av tyskokkuperte Polen som ikke direkte var innlemmet i Tyskland. Området utgjorde omtrent en tredjedel av Polen, men en stor andel av den jødiske befolkningen (rundt to tredjedeler) bodde der. I forbindelse med iverksettelsen av Aktion Reinhard fra sommeren 1942 begynte likvideringene av ghettoene i Generalguvernementet, med påfølgende deportasjoner av jødene. Etter gjennomføringen av de ulike faser av folkemordet, med ghettofisering, likvidering av ghettoer, deportasjoner til «nye bosettinger» og massedrap i konsentrasjons- og dødsleirer, fulgte en periode der titusener av polske jøder befant seg på flukt fra de antijødiske 


\section{VIBEKE MOE}

forfølgelsene. Dette var jøder som hadde unnsluppet de tyskdrevne aksjonene og som i denne perioden i stor grad var avhengige av bistand fra den polske lokalbefolkningen for å overleve. Bokens påstand om at disse menneskene hadde «mere at frygte fra polakker end fra tyskere» (s. 9) må forstås som en beskrivelse av denne akutte situasjonen, ikke som en analyse av ideologi - det er ingen tvil om at målet for den nazistiske politikken var utslettelsen av hele den jødiske befolkningen. Både tyske nazister og ulike deler av den polske befolkningen deltok i aksjonene, men praktiske forhold bidro til å gjøre trusselen fra de polske antisemittene særlig stor i denne fasen. Dette gjaldt ifølge Andersen først og fremst på landsbygda, der det var vanskelig å finne skjul og der angiveri var utbredt. For jøder som skjulte seg på den «kristne» siden i storbyen Warszawa (utenfor ghettoen) var situasjonen annerledes, med flere muligheter til å forsvinne i mengden og dermed høyere overlevelse. Andersen viser her til en overlevelsesrate på 40 prosent (s. 118).

Andersen peker på mange forhold som bidro til å gjøre situasjonen vanskelig for jødene. Fra tysk side ble det utdelt belønninger for deltakelse i antijødiske aksjoner og for å avsløre jøder som lå i skjul, samt at det ble innført dødsstraff for dem som hjalp jødene. Et system med polske «gisler» bidro til å gjøre angiveriet så utbredt. Det forelå også trusler om kollektive straffer. Straff kunne imidlertid unngås hvis man avslørte andre som holdt jøder skjult. Denne kombinasjonen av terror og belønning ble fulgt opp av antijødisk propaganda som skulle påvirke polakkene ideologisk. Imidlertid var den polske antisemittismen intens, utbredt og voldelig - dog ikke genocidal - lenge før krigsutbruddet, og det virker plausibelt når Andersen gjør denne faktoren til hovedforklaring på polakkenes bidrag til folkemordet.

I boken gis det ingen omfattende beskrivelser av antisemittismens historie $\mathrm{i}$ Polen, men noen linjer trekkes i et tidlig kapittel. Fremstillingen berører blant annet betydningen av den katolske kirkes antijudaistiske tradisjon. Sentrale forestillinger i denne tradisjonen, som at «jøden» er kristusmorder, eller den såkalte ritualmordanklagen, der jødene ble beskyldt for å ta livet av kristne spedbarn, lå bak rykteflommer og pogromer gjennom flere hundreår, til etter 2. verdenskrig. Andersen viser også til andre utviklingstrekk i antisemittismens historie, blant annet til fremveksten av en polsk nasjonal selvbevissthet, som definerte jøden som nasjonalt fremmed, og til forestillingen om «jødebolsjeviken». Dette er for øvrig elementer som ikke er særegne for Polen, men som står sentralt i hele den europeiske antijødiske idétradisjon.

Kildegrunnlaget til Andersen utgjøres primært av rettsdokumenter og jødiske vitnemål fremlagt i verkene til den polske psykologen Barbara Engelking og historiker Jan Grabowski. Mange av vitnemålene ble innsamlet i perioden 1945-48, altså $\mathrm{i}$ årene umiddelbart etter krigens slutt. Boken inneholder en del sitater fra materialet, hvilket bidrar til å levendegjøre de dramatiske fortellingene. Det er alltid en viss usikkerhet knyttet til muntlige kilder, ikke minst når det gjelder annenhåndsfortellinger, som det $\mathrm{i}$ stor grad gjør i dette tilfellet. Materialet er imidlertid svært omfattende og inneholder ifølge Andersen mange fellestrekk som styrker troverdigheten. Det er under alle omstendigheter ikke detaljene som er mest sentrale 
i denne presentasjonen, men de bredere tendensene i hendelsesforløpet. Flere av sekundærkildene som Andersen benytter, har skapt oppstandelse i Polen gjennom sine betimelige nyanseringer av en historieformidling der polakkene er blitt fremstilt enten som ofre eller heltemodige redningsmenn under Holocaust. Dette gjelder ikke minst Jan T. Gross, forfatter av boken Naboer, om massakren i byen Jedwabne. En noe mer kritisk distanse til kildene og større grad av drøftelse ville likevel ha styrket Andersens verk. Den polske historikeren Dariusz Stola har blant annet påpekt at både Grabowski og Gross enkelte steder angir tall på usikkert grunnlag. Et eksempel gjelder nettopp massakren i Jedwabne, der Andersen opererer med 1600 jødiske ofre, formodentlig med henvisning til Gross. Anslagene i forskningslitteraturen for øvrig varierer stort, Stola (2003) anslår 400-800 som et rimeligere estimat.

Den polske deltagelsen i jødeforfølgelsene under 2. verdenskrig har vært gjenstand for økende oppmerksomhet de siste tiår, både innen forskning og i skjønnlitteraturen. Palle Andersens bok er et kortfattet, men velskrevet skandinaviskspråklig bidrag til dette arbeidet.

\section{Referanser}

Stola, Dariusz (2003) «Jedwabne: Revisiting the Evidence and Nature of the Crime». Holocaust and Genocide Studies 17(1): 139-152. 